\title{
Pedagogikk og pasjon
}

\author{
- Det går tikkende kunnskapsbomber rundt i de medisinske miljøene, uslepne \\ diamanter som venter på å bli slipt og eksponert! Mange erfarne leger er store, \\ tause kunnskapslagre som bare venter på å bli skolert til flinke og kloke veiledere. \\ Legeforeningens pedagog og hans «Team Pettersen» vil ha en dose pasjon inn \\ i veiledningsrommet.
}

Terje Pettersen har i 15 år kurset leger i hvordan de best kan veilede sine ferskere kolleger. Nå brenner Legeforeningens «huspedagog» for at leger skal forstå nytten av å prioritere veiledning av nye kolleger.

- Det hjelper ikke at man er aldri så faglig flink om man ikke ser verdien av å ivareta yngre kolleger. Fagmiljøene utarmes jo om ikke kunnskapen distribueres til neste generasjon! Av-intellektualiseringen starter der det ikke læres bort annet enn blind praksis!

Pettersens engasjement kan ikke kalles annet enn glødende, for han skulle så gjerne sett at de tikkende kunnskapsbombene i hvit frakk detonerte litt oftere. Han lener seg over bordet og setter øynene i meg. - Mange erfarne leger er store, tause kunnskapslagre som bare venter på å bli skolert til flinke og kloke veiledere! Kunnskapen og erfaringen de bærer på bør gjøres mer tilgjengelig for yngre leger. Kunnskap blir jo først varig når den deles med andre. Beholder du den bare for deg selv, blir den jo borte før eller siden, filosoferer han.

\section{Overlevering av kunnskap}

Terje Pettersen har sett seg lei på at sykehusmiljøene ikke prioriterer veiledning av de ferske legene, og understreker nødvendigheten av at legene får på plass pedagogiske rutiner som aktivt overleverer kunnskap til neste kollegagenerasjon.

- Hvis du er flink til noe, bør du prøve å lære dette bort. Der det utdannes dyktige leger, er det også dyktige leger rundt dem som utdannes. Det er jo ingen som vokser ut av et faglig vakuum. Travelheten stjeler dessverre av tiden man trenger til fordypning og refleksjon, men mange leger fortsetter jo å jobbe nettopp der de er utdannet, så hvorfor ikke gi dem det beste når de først er i spesialisering? Man skaper da sine egne dyktige kolleger. Jeg fikk et sitat av en sykehuslege som var sterkt engasjert i veiledning: - If you think education is expensive, try having an accident! Det illustrerer vel hvor kostbart det kan bli å nedprioritere veiledning?

\section{Rom for refleksjon}

Terje Pettersen klarer ikke skjule iveren etter å få oss leger til å forstå at vi må være kunnskapsformidlere, alle som én. Det skinner igjennom at det ikke alltid har vært like enkelt å få gehør for denne kongstanken i fagmiljøer der det jobbes etter produksjonsprinsippet.

- Når effektivitetskravene øker, kan kvaliteten på veiledningen bli omvendt proporsjonal med produktiviteten. Mange leger får, til tross for sin motivasjon og forståelse, dessverre ikke tid eller anledning til å prioritere veiledning i en hektisk hverdag. De blir kneblet av et ugunstig arbeidspress i stadig større administrative og faglige miljøer. Slike forhold gjør det vanskeligere å få plass til veiledningssamtaler og et overordnet fokus på opplæring. På kursene våre forsøker vi å se etter hva veilederne selv kan skape av muligheter for læring. Bruk derfor anledningene når de er der, oppfordrer pedagogen.

\section{Systematisk fagutvikling}

Terje Pettersen opplever at denne utviklingen ikke er i samsvar med hvordan kunnskapsutveksling prioriteres i andre yrkeskulturer.

- I andre kunnskapsbedrifter er veiledning og opplæring av yngre kolleger en selvfølge, og det ville være utenkelig å sette ferske medarbeidere i sving og be dem finne ut av alt selv. Det finnes nøye gjennomtenkte systemer for opplæring og feedback. I en del sykehusmiljøer satser man på at dyktige fagpersoner vokser frem av seg selv, men så enkelt er det ikke. Et sykehus er en kunnskapsbedrift der humankapitalen blir avgjørende, og den holdes ved like av systematisk faglig utvikling. Uten tilstrekkelig kompetente leger og medarbeidere, kan det gå galt!

Det som karakteriserer vellykkede organisasjoner er ifølge Terje Pettersen at de har evnen til omsorg og kunnskap. Han forteller om såkalte refleksive rom - faste møteplasser der kolleger opplever en slik tilhørighet at de fritt kan beskrive, dele, få ny informasjon og evalueringer. Slik kan de stadig fornye sin personlige kunnskap.

- I disse organisasjonene er det en etablert tankegang at veiledning har stor gevinst på sikt. Dette må mer inn hos oss! Når flere mennesker bærer de samme erfaringene, blir jo kunnskapen værende i organisasjonen selv om enkeltmennesker forsvinner. På kursene våre forsøker vi å bevisstgjøre legene på rollen som veiledere; at man må se sin veilederfunksjon i et større perspektiv. Hvis du er flink til noe, blir du enda flinkere av å lære det fra deg. Dessuten varer du lenger i faget hvis du får mulighet til å lære bort ting, og der ligger det en stor sekundærgevinst for dem som er flinke til å utdanne, påpeker han.

\section{Tikkende kunnskapsbomber}

I løpet av karrieren som pedagog tilknyttet Legeforeningen har Terje Pettersen gjort seg varierte erfaringer om hvilke kunnskapskulturer som eksisterer i de ulike legemiljøene. Hvordan står det så egentlig til på veiledningsfronten?

- Jeg oppdaget raskt at leger som skal utdanne andre leger først selv må finne gevinsten i å gi veiledning og tilrettelegge for læring. På de avdelinger der man ser at dette er fordelaktig for egen situasjon, der tilrettelegges det for veiledning og systematisk opplæring. Dersom erfarne leger selv har opplevd nyttig veiledning, er det ofte en selvfølge at dette videreføres. Men om de selv har opplevd tilfeldigheter og ignorering, kan det være vanskeligere. De må 


\section{Terje Pettersen}

Født 30. mars 1953

- Cand.paed. Universitetet i Oslo 1984

- Seniorrådgiver ved Statens arbeidsmiljøinstitutt Oslo, Avdeling for organisatorisk og psykososialt arbeidsmiljø

- Ekstern pedagogisk konsulent for Den norske legeforening, seksjon for utdanning/medisinsk fagavdeling

- Tidligere lektor ved Volda lærerhøgskole og høyskolelektor ved Hærens krigsskole Oslo

Foto Anne Kathrine Sebjørnsen

først forstå hvor viktig det er at det kommer noen etter dem som kan videreføre faget og kulturen. Deretter kan de hente frem lederen og kulturbyggeren i seg!

\section{Skolering av gruppeveiledere}

Utdanning av gruppeveiledere i allmenn-, arbeids- og samfunnsmedisin har også høy prioritet i Legeforeningen. Her har Terje Pettersen et fruktbart samarbeid med Legeforeningens veiledningskoordinatorer Kristin Prestegaard, Bente Aschim, Peter Prytz og Sverre Lundevall. Arbeidet koordinatorene nedlegger mellom hvert kurs er omfattende. Han insisterer på å få gi en verbal blomst til apparatet i Legeforeningen som ser verdien av denne bevisstgjøringen omkring veiledning, samt til arbeidsgiveren Statens arbeidsmiljøinstitutt som legger til rette for at han kan fortsette å holde kurs på si. Legeforeningens huspedagog og hans «Team Pettersen» har etter hvert fått litt av en gurustatus, noe han selv forklarer med at leger er veldig interessert $\mathrm{i}$ pedagogikk. Kanskje skyldes det at vi er sultefôret på den slags i hverdagen?

- Jeg har ofte lurt på hvorfor leger er så opptatt av pedagogikk, og har kommet frem til at rollene som lege og lærer er ganske like. Det er uselviske, altruistiske roller, man er velgjørere som skal hjelpe andre til å lykkes. Mange leger er dessuten formidlere. I legestudiet blir man skolert til å arbeide raskt og riktig, men ikke nødvendigvis i formidlingskunst. Jeg opplever en voldsom kunnskapstørst hos kursdeltakerne våre, det er tydeligvis en veldig motivert gruppe mennesker som melder seg på disse kursene. Jeg tror mange opplever at det går et lys opp for dem når de får noen verktøy å jobbe med, forteller Pettersen.

\section{Pasjon for veiledning}

Som uskolert veileder kan man ofte kjenne på hjelpeløshet og usikkerhet. På veilederkursene får man et innblikk i veiledningsmetodikk og prinsipper for gruppebasert veiledning, samt at man lærer noen praktiske måter å gjennomføre veiledningen på. Terje Pettersen har latt seg imponere av kunnskapsnivået blant norske leger, men har inntrykk av at mange kan bli bedre på å formidle sin kunnskap videre.

- Jeg er grundig imponert over den store innsikten som sykehusspesialistene besitter, og over klokskapen og oversikten man finner innen allmenn-, arbeids- og samfunnsmedisin. Det går tikkende kunnskapsbomber rundt i de medisinske miljøer, uslepne diamanter som bare venter på å bli slipt og eksponert! Vi bevisstgjør dem på at de må gjøre sin kunnskap tilgjengelig for andre. Kursene bryter nok litt med hva de hadde forventet, men de fleste gir tilbakemeldinger på at det er nyttige tanker vi planter hos dem, forteller Pettersen.

Et fag blir fort kjedelig hvis man ikke kjenner historien bak den praksisen man utøver. Likeledes blir veiledning ensformig om veilederen kun er opptatt av det fagtekniske. Legeforeningens pedagog forsøker å få kursdeltakerne sine til å grave litt dypere, forbi det tekniske nivået og ned til det personlige planet, det akademiske grunnlaget og helt frem til det metafysiske nivået. Han vil rett og slett ha en dose pasjon inn i veiledningsrommet!

- Det er en bekymring at mange leger bare har tid til å formidle den instrumentelle biten av faget. Ofte er det ikke kultur for å bli personlig. Man resonnerer ikke over hvilket faktagrunnlag man bygger sin kunnskap på, og man filosoferer lite rundt medisinske avgjørelser. Man lærer blind praksis uten å kjenne sitt fags historie. Det er her av-akademiseringen starter, sier Pettersen og rynker pannen.

- Er det ikke rart, forresten, at vi som voksne glemmer det elementære for å bli skikkelig god til noe? Da du var barn og ønsket å bli god til å spille gitar eller piano, da var du jo nødt til å øve for å lykkes. Og du kunne jo heller ikke forvente å få spille fotballkamp uten å trene? Noen ganger trenger vi korreksjon for å bli bedre i arbeidslivet også, sier han idet han får krampe i den høyre leggen. Han spilte nemlig innebandy med en gjeng naboer i femtiårene i går, og det er blodig alvor.

Da snakker vi om pasjon, sier Pettersen og flirer.

Og det er visst det som må til.

\section{Anne Kathrine Sebjørnsen}

annekaths@hotmail.com

BUP Nordstrand

0621 Oslo 